\title{
Histomorphological Response of Dogs' Dental Pulp Capped with White Mineral Trioxide Aggregate
}

\author{
Italo Medeiros FARACO JUNIOR ${ }^{1}$ \\ Roberto HOLLAND ${ }^{2}$ \\ ${ }^{1}$ Department of Pediatric Dentistry, Faculty of Dentistry, Lutheran University of Brazil, ULBRA, Canoas, RS, Brazil \\ ${ }^{2}$ Department of Restorative Dentistry, Faculty of Dentistry of Araçatuba, UNESP, Araçatuba, SP, Brazil
}

\begin{abstract}
This study was conducted to observe the response of dogs' dental pulp to white mineral trioxide aggregate (MTA) when used as pulp capping material. The pulp of 15 dogs' teeth was experimentally exposed and capped with white MTA. The animals were sacrificed two months later and the specimens were prepared for histomorphological study. The pulp capped with white MTA showed a healing process with complete dentin bridge formation in all samples. In some cases, there was not a tubular dentin shape, but only a structure with an interesting morphological aspect sealing the exposure site. Only 2 specimens exhibited pulp inflammation. In conclusion, the data obtained in this study showed that white MTA has the necessary properties of a pulp capping material.
\end{abstract}

Key Words: dental pulp capping, mineral trioxide aggregate.

\section{INTRODUCTION}

A considerable number of articles about mineral trioxide aggregate (MTA) have been published in the dental literature. Most of the studies with this material have evaluated its sealing performance (1-3), tissue response (4-8), mutagenicity potential (9), cytotoxicity (10-11) and physical characteristics (12).

The data available about the use of MTA in conservative pulp treatment have shown good biological properties and results. Deposition of neoformed hard tissue in direct contact with MTA was observed in cases of pulp capping and pulpotomy. Pitt Ford et al. (13) capped monkey pulps and found mineralized tissue bridge in all specimens. In only one case, pulp inflammation was reported. Soares (14) observed that the mineralized bridge occurred in $96.43 \%$ of the specimens after pulpotomy with MTA. Junn et al. (15) has reported that pulp capped with MTA exhibited less inflammation and higher dentin bridge formation than the group treated with calcium hydroxide. Faraco Junior and Holland (16) reported a healing process with complete tubular dentin bridge formation and no in- flammation in any of the dog pulps capped with MTA. Holland et al. (17) also observed in dogs' pulp hard tissue and vital pulps without any inflammatory reaction in almost all specimens after pulpotomy with MTA.

The color of the material used was not described in most of the above-mentioned papers. We suspect that it was the gray MTA, because the only commercially available MTA had a gray powder (ProRoot MTA, Dentsply, Tulsa, OK, USA). According to Glickman and Koch (18), the use of gray MTA could potentially stain the tooth structure in areas where esthetics is an issue.

Only Holland et al. $(19,20)$ compared the two materials (white and gray MTA) in rat subcutaneous connective tissue. They reported that the mechanism of action of white MTA is very similar to that reported for gray MTA.

Nevertheless, the biological difference between the gray and the white MTA in pulp capping is unknown. Thus, the purpose of this study was to analyze the response of dog dental pulps after capping with white MTA. 


\section{MATERIAL AND METHODS}

Fifteen teeth of three 8-month-old dogs were used in this study. Under general anesthesia with sodium pentobarbital injected intravenously and with a rubber dam in place, cavities were prepared in the labial surface of each tooth. Standardized pulp exposure (0.5 millimeter in diameter) was done with a \#2173 modified bur at high speed and copious water spray. Bleeding was controlled by irrigation with sterile water and cotton pellets before placing the pulp capping material.

The material used was white MTA (Loma Linda University, Loma Linda, CA). The MTA power was mixed with sterile saline solution and applied to the exposure site. The remaining cavity preparation of every tooth was filled with zinc oxide-eugenol cement (SSW Artigos Dentário Ltda., Rio de Janeiro, RJ, Brazil).

After a postoperative period of 60 days, the animals were sacrificed by perfusion. The teeth were extracted, fixed in 10\% neutral-buffered formalin solution and decalcified in formic acid-sodium citrate. The specimens were embedded in paraffin, serially sectioned to an average thickness of $6 \mu \mathrm{m}$ and stained with hematoxylin and eosin and the Brown-Brenn technique.

The results were evaluated by one of the authors, according to the criteria described below. Each histomorphological event was evaluated by scores of 1 to 4 , with 1 being the best result and 4 the worst result.

\footnotetext{
Hard tissue bridge

Continuity

1. complete

2. little communication of the capping material with dental pulp

3. only lateral deposition of hard tissue on the walls of the cavity of pulp exposition

4. absence of hard tissue bridge and absence of lateral deposition of hard tissue

Morphology

1. dentin or dentin and irregular hard tissue

2. only irregular hard tissue deposition

3. only a slight layer of hard tissue deposition

4. no hard tissue deposition

Thickness (evaluated with a micrometric ocular in three different points of the bridge)

1. up to $250 \mu \mathrm{m}$

2. from 150 to $249 \mu \mathrm{m}$

3. from 1 to $149 \mu \mathrm{m}$

4. partial or absent bridge
}

Localization

1. closure to the exposition area without invading the pulp space

2. bridge invading pulp space next to the opposite dentin wall

3. bridge reached the opposite dentin wall

4. no bridge or only hard tissue deposition on the walls of the exposition cavity

\section{Dental pulp}

Intensity of inflammatory reaction (acute and chronic processes) (evaluated in different places with a magnification of 400X)

1. absent or very few cells

2. mild: average number less than 10 cells

3. moderate: average number $10-25$ cells

4. severe: average number greater than 25 cells

Extension of the inflammatory reaction (acute and chronic processes)

1. absent

2. mild: inflammatory cells only next to dentin bridge or area of pulp exposition

3. moderate: inflammatory cells are observed in part of the coronal pulp

4. severe: all coronal pulp is infiltrated or necrosed

General state of the pulp

1. no inflammatory reaction

2. with inflammatory reaction

3. abscess

4. necrosis

Giant cells and particles of the capping material

1. absent

2. mild

3. moderate

4. large number or pulp necrosis

Presence of microorganisms

1. absent

4. present

\section{RESULTS}

There were hard tissue bridges in all specimens, without a superficial necrosis zone and without defects allowing communication between dental pulp and capping material. Therefore, hard tissue bridges were considered complete in all specimens (Figures 1 and 2). In 5 cases, however, there was no tubular dentin but only a structure with an interesting morphologic aspect. In these cases, there were bridges full of vacuole-like spaces with varied shape and dimensions without communication with each other. Between those vacuoles, there was an amorphous eosinophilic structure. This aspect was similar to the morphological structure of the 
capping material that, however, exhibited different color (Figure 3). Two specimens exhibited a hard tissue bridge in the position that resembled a pulpotomy. In these two cases, the pulp exposure occurred near the pulp horn and the capping material was accidentally projected to the space of the pulp horn (Figure 2). A very few cases of tunnel defects were observed, but they were sealed in areas nearest to the capping material. Pulp tissues were vital in all cases. A severe acute and chronic inflammatory response and hyperemic vessels were noted in only one case in which the pulp

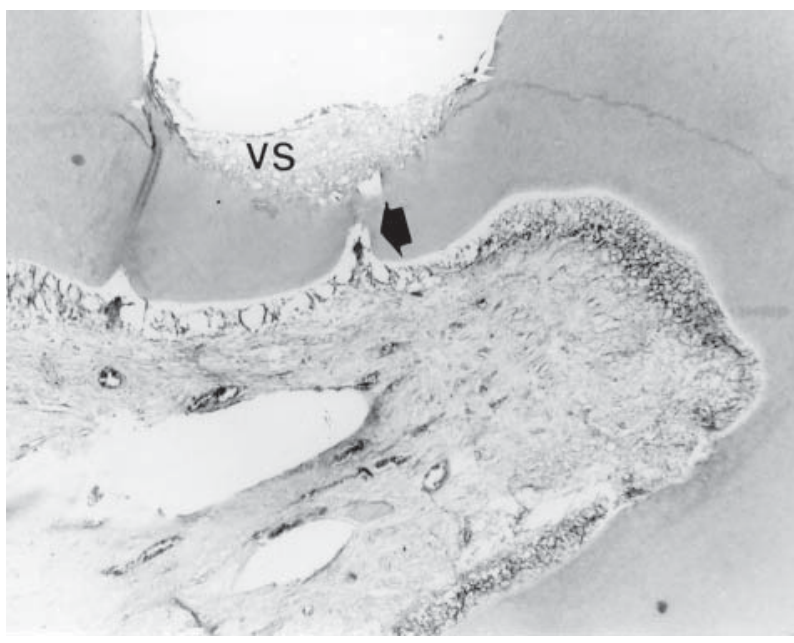

Figure 1. There is a tubular hard tissue bridge with a tunnel defect (arrow) and with vacuole-like structure (VS). There is no inflammatory reaction in the dental pulp (Hematoxylin and eosin; original magnification X40).

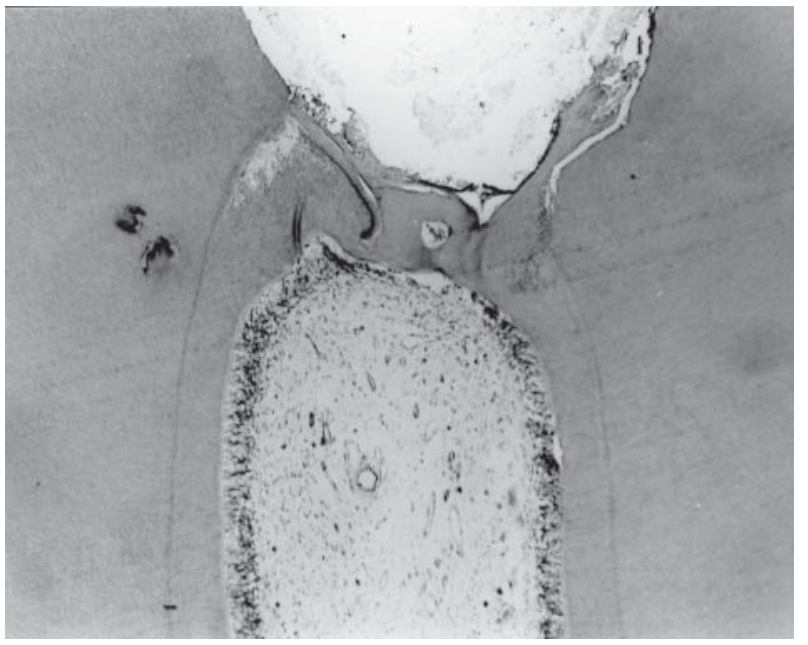

Figure 2. Observe a hard tissue bridge in the position that resembles a pulpotomy. There is no inflammatory reaction in the pulp tissue (Hematoxylin and eosin; original magnification X40). exposure was covered by a non-tubular bridge, as already described. In this specimen, a few Gram-positive cocci were detected in the pulp tissue next to the exposure site. In the other specimens, microorganisms were not observed. In one case, the inflammatory cells were mild and restricted to a small area next to the cavity preparation.

The average scores attributed to all specimens of the experimental group can be observed in Table 1.

\section{DISCUSSION}

The data presented in this report are of the experimental group of another investigation developed in dogs' teeth (16). This investigation studied the gray and white MTA before the materials were available commercially. When we noted that only the gray MTA was on the market, without any explanation, we believed that white MTA would not be available. In view of this, we decided not to publish the results with white MTA. Nevertheless, the paper of Glickman and Koch (18) gave new life to the white MTA. Therefore, the results of the control group of the present report have been previously published (16).

The favorable results obtained in this research using white MTA are similar to the findings of others in direct pulp capping $(13,15,16)$ and in pulpotomies $(14,17)$ using gray MTA.

In the present paper, hard tissue bridge formation was observed in all specimens capped with white

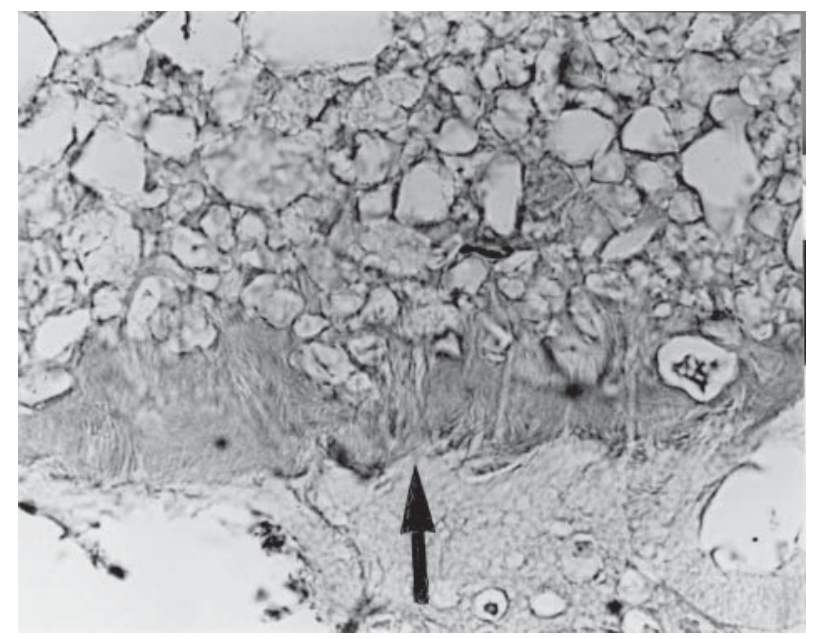

Figure 3. There is a layer of vacuole-like structure with eosinophilic walls. Tubular dentine is being deposited (arrow) against that structure (Hematoxylin and eosin; original magnification X400). 
MTA, without a superficial necrotic zone. In some cases, there was no tubular dentin, but only a structure with an interesting morphological aspect sealing the pulp exposure. Many vacuole-like bridges with varied dimensions not interlinked with each other were present in these cases. Between these vacuoles, there was an amorphous eosinophilic structure. This irregular structure was also described by Holland et al. (19) and we do not know its exact nature; however, it resembles the structure of the capping material.

A few tunnel defects were observed, but they were restricted to the portion nearest to the capping material. This fact was also observed by Pitt Ford et al. (13) and Soares (14). According to Pitt Ford et al. (13), a hard tissue bridge next to MTA may occur due to its sealing ability (1-3), biocompatibility (4-8), alkalinity (12) or other associated proprieties.

In our investigation, pulp tissue showed vitality in all cases. The cells in the odontoblastic layer were reduced in number nearest to the pulp exposure. Severe acute and chronic inflammatory infiltrate and hyperemic vessels were noted in only one case of the white MTA. In this specimen, few Gram-positive cocci were detected in the pulp tissue next to the exposed area. In the other specimens, no microorganisms were observed. Absence of bacteria is due to the sealing properties of MTA, as already reported in many papers (1-3).
In our research, as already mentioned, we observed some morphological differences of hard tissues bridges obtained by white and gray MTA. We also verified, during manipulation of these materials, that gray MTA setting time was lower than that of white MTA. According to Holland et al. (19), the mechanism of action of white MTA is very similar to that reported for gray MTA (20). They observed granulations birefringent to polarized light at the opening of dentin tubes filled with white MTA. These granulations were similar to the calcite crystals observed with calcium hydroxide. MTA has no calcium hydroxide, but rather calcium oxide that could react with tissue fluids to form calcium hydroxide. Next to these granulations, there was a deposit of von Kossa-positive hard tissue that resembled a mineralized bridge.

In conclusion, the observed results and the mechanism of action of white MTA were very similar to that reported for gray MTA (16). Considering these results, we believe that the white MTA may be considered to be an effective pulp capping material.

\section{RESUMO}

Foi objetivo deste trabalho estudar a reação do tecido pulpar ao capeamento com agregado de trióxido mineral (MTA) branco. Para isto, foram utilizados 15 dentes de cães, onde após o preparo de cavidades na região cervical da face vestibular e exposição

Table 1. Scores attributed to the specimens.

\begin{tabular}{|c|c|c|c|c|c|c|c|c|c|c|c|c|c|c|c|c|c|c|c|}
\hline \multicolumn{4}{|c|}{ Specimen number } & 1 & 2 & 3 & 4 & 5 & 6 & 7 & 8 & 9 & 10 & 11 & 12 & 13 & 14 & 15 & Score Average \\
\hline \multirow{4}{*}{\multicolumn{2}{|c|}{$\begin{array}{l}\mathrm{B} \\
\mathrm{r} \\
\mathrm{i} \\
\mathrm{d} \\
\mathrm{g} \\
\mathrm{e}\end{array}$}} & \multicolumn{2}{|c|}{ Continuity } & 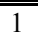 & 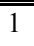 & 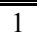 & 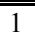 & 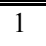 & 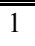 & 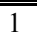 & 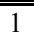 & 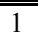 & 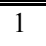 & 1 & 1 & 1 & 1 & 1 & 1.00 \\
\hline & & \multicolumn{2}{|c|}{ Morphology } & 2 & 2 & 2 & 1 & 2 & 1 & 1 & 1 & 1 & 1 & 1 & 1 & 2 & 1 & 1 & 1.33 \\
\hline & & \multicolumn{2}{|c|}{ Thickness } & 2 & 3 & 2 & 1 & 3 & 2 & 2 & 2 & 1 & 2 & 1 & 2 & 3 & 3 & 3 & 2.13 \\
\hline & & \multicolumn{2}{|l|}{ Location } & 1 & 1 & 1 & 3 & 1 & 1 & 1 & 1 & 1 & 3 & 1 & 2 & 1 & 1 & 1 & 1.33 \\
\hline \multirow{5}{*}{$\begin{array}{c}\mathrm{D} \\
\mathrm{e} \\
\mathrm{n} \\
\mathrm{t} \\
\mathrm{a} \\
\mathrm{l}\end{array}$} & \multirow{4}{*}{$\begin{array}{l}\mathrm{I} \\
\mathrm{n} \\
\mathrm{f} \\
\mathrm{l} \\
\mathrm{a} \\
\mathrm{m} .\end{array}$} & \multirow[t]{2}{*}{ Acute } & Intensity & 1 & 1 & 1 & 1 & 4 & 1 & 1 & 1 & 1 & 1 & 1 & 1 & 1 & 1 & 1 & 1.20 \\
\hline & & & Extention & 1 & 1 & 1 & 1 & 3 & 1 & 1 & 1 & 1 & 1 & 1 & 1 & 1 & 1 & 1 & 1.13 \\
\hline & & \multirow[t]{2}{*}{ Chronic } & Intensity & 1 & 1 & 1 & 1 & 4 & 1 & 1 & 2 & 1 & 1 & 1 & 1 & 1 & 1 & 1 & 1.26 \\
\hline & & & Extention & 1 & 1 & 1 & 1 & 4 & 1 & 1 & 2 & 1 & 1 & 1 & 1 & 1 & 1 & 1 & 1.26 \\
\hline & \multicolumn{3}{|c|}{ General state } & 1 & 1 & 1 & 1 & 2 & 1 & 1 & 2 & 1 & 1 & 1 & 1 & 1 & 1 & 1 & 1.13 \\
\hline \multirow{3}{*}{$\begin{array}{l}\mathrm{P} \\
\mathrm{u} \\
1 \\
\mathrm{p}\end{array}$} & \multicolumn{3}{|c|}{ Giantcells } & 1 & 1 & 1 & 1 & 2 & 1 & 1 & 1 & 1 & 1 & 1 & 1 & 1 & 1 & 1 & 1.06 \\
\hline & \multicolumn{3}{|c|}{ Particles of capping material } & 1 & 1 & 1 & 1 & 2 & 1 & 1 & 1 & 1 & 1 & 1 & 1 & 1 & 1 & 1 & 1.06 \\
\hline & \multicolumn{3}{|c|}{ Microorganisms } & 1 & 1 & 1 & 1 & 4 & 1 & 1 & 1 & 1 & 1 & 1 & 1 & 1 & 1 & 1 & 1.20 \\
\hline & & & & & & & & & & & & & & & & & & & 1.25 \\
\hline
\end{tabular}


pulpar, estas foram capeadas com MTA branco. Os animais foram sacrificados após 60 dias do término dos procedimentos clínicos e os dentes processados em laboratório para obtenção de cortes histológicos. Foi observada formação de ponte de tecido duro em todas as polpas. Em alguns casos, não havia dentina tubular mas somente uma estrutura de aspecto morfológico peculiar, selando a cavidade de exposição pulpar. Apenas dois casos apresentaram inflamação pulpar. Conclui-se que o MTA branco possui as características necessárias de um material para capeamento pulpar.

\section{REFERENCES}

1. Torabinejad M, Higa RK, McKendry DJ, Pitt Ford IR. Dye leakage of four root end filling materials: effect of blood contamination. J Endodon 1994;20:159-163.

2. Nakata TT, Bae KC, Baumgarther JC. Perforation repair comparing mineral trioxide aggregate and amalgam using an anaerobic bacterial leakage model. J Endodon 1998;24:184-186.

3. Wu M, Kontakiotis EG, Wesseiink PR. Long-term seal provided by some root-end filling materials. J Endodon 1998;24:557-560.

4. Pitt Ford TR, Torabinejad M, McKendry DJ, Hong CU, Kariyawasam SP. Use of mineral trioxide aggregate for repair of furcal perforations. Oral Surg Oral Med Oral Pathol Oral Radiol Endod 1995;79:756-762.

5. Torabinejad M, Hong CU, Pitt Ford TR, Kariyawasam SP. Tissue reaction to implanted Super-EBA and mineral trioxide aggregate in the mandible of guinea pigs: a preliminary report. J Endodon 1995;21:569-571.

6. Torabinejad M, Pitt Ford TR, McKendry DJ, Abedi HR, Miller DA, Kariyawasam SP. Histologic assessment of mineral trioxide aggregate as a root end filling in monkeys. J Endodon 1997;23:225-228.

7. Holland R, Souza V, Nery MJ, Otoboni Filho JA, Dezan Junior E. Reaction of dog's teeth to root canal filling with mineral trioxide aggregate or glass ionomer sealer. J Endodon 1999;25:728-730.

8. Koh ET, McDonald F, Pitt Ford TR, Torabinejad M. Cellular response to mineral trioxide aggregate. J Endodon 1998;24:543547.
9. Kettering JD, Torabinejad M. Investigation of mutagenicity of mineral trioxide aggregate and other commonly used root-end filling materials. J Endodon 1995;21:537-539.

10. Torabinejad M, Hong CU, Pitt Ford TR, Kettering JD. Cytotoxicity of four root end filling materials. J Endodon 1995;21:489492.

11. Osorio RM, Hefti A, Vertucci FJ, Shawley AL. Cytotoxicity of endodontic materials. J Endodon 1998;24:91-96.

12. Torabinejad M, Hong CU, McDonald F, Pitt Ford IR. Physical and chemical properties of a new root-end fiiling material. $\mathrm{J}$ Endodon 1995;21:349-353.

13. Pitt Ford TR, Torabinejad M, Abedi HR, Backland LK, Kariyawasam SP. Using mineral trioxide aggregate as a pulpcapping material. J Am Dent Assoc 1996;127:1491-1494.

14. Soares IML. Resposta pulpar ao MTA - agregado de trióxido mineral - comparada ao hidróxido de cálcio, em pulpotomias: histológico em dentes de cães. [Thesis], Brazil: Faculdade de Odontologia, UFSC, 1996.

15. Junn DJ, McMillian P, Backland LK, Torabinejad M. Quantitative assessment of dentin bridge formation following pulp capping with mineral trioxide aggregate. J Endodon 1998;24:278 (Abstract).

16. Faraco Junior IM, Holland R. Response of the pulp of dogs to capping with mineral trioxide aggregate or calcium hydroxide cement. Dent Traumatol 2001;17:163-166.

17. Holland R, Souza V, Murata SS, Nery MJ, Bernabé PFE, Otoboni Filho JA, Dezan Junior E. Healing process of dog dental pulp after pulpotomy and pulp covering with mineral trioxide aggregate or Portland cement. Braz Dent J 2001;12:109-113.

18. Glickman HN, Koch K. $21^{\text {st }}-$ Century endodontics. J Am Dent Assoc 2000;131:39S-46S.

19. Holland R, Souza V, Nery MJ, Faraco Junior IM, Otoboni Filho JA, Bernabé PFE, Dezan Junior E. Reaction of rat connective tissue to implanted dentin tubes filled with a white mineral trioxide aggregate. Braz Dent J 2002;13:23-26.

20. Holland R, Souza V, Nery MJ, Otoboni Filho JA, Bernabé PFE, Dezan Junior E. Reaction of rat connective tissue to implanted dentin tubes filled with mineral trioxide aggregate or calcium hydroxide. J Endodon 1999;25:161-166. 